\title{
A comparative approach to the Croatian and Montenegrin small-scale fisheries (SSF) in the coastal eastern Adriatic Sea: fishing gears and target species
}

\author{
Sanja MATIĆ-SKOKO ${ }^{1}$, Zdravko IKICA $^{2}$, Dario VRDOLJAK ${ }^{1}$, Melita PEHARDA ${ }^{1}$, \\ Pero TUTMAN ${ }^{1}$, Branko DRAGIČEVIĆ ${ }^{1}$, Aleksandar JOKSIMOVIĆ ${ }^{2}$, \\ Jakov DULČIĆ ${ }^{1}$, Mirko ĐUROVIĆ ${ }^{2}$, Milica MANDIĆ ${ }^{2}$, Olivera MARKOVIĆ ${ }^{2}$, \\ Nika STAGLIČIĆ ${ }^{1}$ and Ana PEŠIĆ2*
}

${ }^{1}$ Institute of Oceanography and Fisheries, Šetalište I. Meštrovića 63, 21000 Split, Croatia

${ }^{2}$ Institute of Marine Biology, University of Montenegro, Dobrota b.b., P.O. Box 69, 85330 Kotor, Montenegro

*Corresponding author: pesica@ac.me

Small-scale fisheries (SSF) in Croatia and Montenegro have a long tradition, similar to those of SSFs in other parts of the coastal Mediterranean. In order to improve fisheries management and save the cultural heritage of fishing traditions on the eastern Adriatic coast, scientists and fisheries managers, from these two countries, made an effort, to gain a better understanding of fishing activities and targeted stocks. This is a complex research topic, due to the high and increasing fishing pressure on marine resources as well as the fact that fisheries management throughout the Mediterranean region remains conventional in its nature. Basic characteristics of SSFs in each country are presented. Specific conclusions related to improvement of coastal resources state in term of sustainable use are suggested together with proposal for additional conservation measures and actively involving fishermen in the management process. Finally, guidelines for future management in terms of monitoring and data collection framework (DCF) are proposed for both countries.

Key words: Small-scale fisheries, Adriatic Sea, Croatia, Montenegro

\section{INTRODUCTION}

Small-scale fisheries (SSF) in Croatia and Montenegro, as well as in other parts of the Mediterranean is a very important component in the exploitation of marine resources and it is mainly managed through a combination of effort-control and technical measures (PAPA-
CONSTANTINOU \& FARRUGIO, 2000; LLEONART \& MAYNOU, 2003; MATIĆ-SKOKO et al., 2011a). Generally, those SSF as the Mediterranean ones comprise large fishing fleets, scattered along an extensive coastline and are thus difficult to monitor; individual fisheries generating relatively low catches per fishing day and vessel and their catch often goes unrecorded, being directly 
supplied to market (TZANATOS et al., 2013). Most fisheries along the eastern Adriatic coast, as in the whole southern Europe, are multi-species (i.e. the catch of a fishing gear is composed of a variety of species) and multi-gear (the same species is fished by a variety of fishing gears). In addition, fishing behavior can be unpredictable and this creates problems for fisheries management (SALAS \& GAERTNER, 2004). Furthermore, data collection in Croatia has only been carried out on a continuous and standardized basis in the last decade, particularly after 2012 when data collection within Data Collection Framework (DCF) started. There is currently no systematic data collection for small-scale fisheries in Montenegro. Data collection within Data Collection Framework is scheduled to start in 2017.

The importance of small-scale fisheries (SSF) in the coastal Mediterranean is highlighted in last few years. According to the available data, for the Mediterranean \& Black Sea fleet, the small scale fleet (SSF) possessed $69 \%$ of the fleet in number and accounted for $67 \%$ of the effort but provided jobs for only $51 \%$ of the total number of people employed in fishing fleets. In terms of production, the SSF landed only $13 \%$ in weight but $23 \%$ in value; generating overall $27 \%$ of the revenue (STEFC, 2014). Although, estimations of the General Commission for Fisheries in the Mediterranean (GFCM) are slightly different in term of numbers, they highlight that SSF exemplify sustainable resource use: exploiting living marine resources in a way that minimizes environmental degradation while maximizing economic and social benefits. In the period up to 1990, the Adriatic Sea was in the second place among the 10 fishing areas in the Mediterranean, when fishing and its economic importance are considered. Several countries participate in total fishing activities in the Adriatic Sea, i.e. Italy $(80 \%)$, Croatia (17\%), Slovenia (2\%), Albania (2.6\%) and Montenegro (0.3\%) (JARDAS, 1996). Croatia is the most important coastal fishing country on the eastern Adriatic coast in terms of landings of marine capture fisheries while Montenegro is on the fourth place. Traditionally, in Croatia, marine resources have been distinguished as pelagic, demersal and coastal, even though there is no clear distinction between them in nature (JARDAS \& PALLAORO, 1997). The same is the case in the Montenegro (IKICA et al., 2013; PEŠIĆ et al., 2016).

Small scale low impact activities of SSF, using passive gears applied in a non-intensive and seasonally polyvalent manner also provide a ready-made solution to the problems of overfishing and environmental degradation caused by larger scale intensive, industrial fishery activities (CFP, 2014), as it is highlighted in reformed Common Fisheries Policy (CFP). However, although fishery activities undoubtedly have a significant impact on fish stocks and on the marine habitats essential for fishery production, the Mediterranean is also highly vulnerable to the impacts of human activities (STAGLIČIĆ et al., 2011). Including Gibraltar and Monaco there are 23 countries bordering the Mediterranean, and the impacts of industrial and domestic sources of pollution are considerable, as are the impacts of port, shipping, and offshore oil and gas exploration and extraction, and the actual and potential impacts of climate change (TZANATOS et al., 2014). Of course, considerable environmental impact is also being caused by the unrestricted use of small-meshed monofilament gillnets, and the associated effects of ghost fishing (TUTMAN et al., 2015).

Scientists and fishery managers in this region have started making effort to gain a better understanding of the fishing activities and the stocks targeted, in order to improve their management and to save the cultural heritage of fishing traditions in coastal communities. However, the Mediterranean basin is a semi-enclosed sea and to a large extent its resources complete their life cycle within it. The same is valid for the Adriatic Sea. Therefore, only an integrated approach can answer the needs of an appropriate fishery resources management in this region. In order to plan and improve management measures, an important objective becomes the detailed knowledge of all Mediterranean coastal fishing activities (BATTAGLIA et al., 2010), together with spatial planning for fisheries (BASTARDIE et al., 2017). Also in recent years, seasonal closing of fishing grounds or proclamation of marine 
protected areas are increasingly advocated as a management tool for restoring fish resources and ensuring the sustainability of their exploitation (FRANCOUR et al., 2001, ROBERTS et al., 2005). The main objective of this study is to present comparison of the Croatian and Montenegrin small-scale fisheries (SSF) in the coastal eastern Adriatic Sea with the special focus on differences in seasonality of using fishing gears and target species.

\section{Croatia}

Baseline regulation framework governing fisheries issues in Croatia is reported by MATIĆSKOKO et al. (2011a, 2011b). Although, there is no explicit definition of SSF in Croatian legislative, usually it is considered as commercial, multigear fisheries operating with vessels $<12 \mathrm{~m}$ using all static gears (nets, hooks and long lines, traps) and shore seines since they are traditional, relatively small sized fishing gear and operating with small fishing vessels not far from the shore. This fishery is carried out within the distance of one nautical mile from the mainland and islands coasts, in the shallow water at the depth of no more than approximately $80 \mathrm{~m}$ which represents a little more than $3 \%$ of the total surface of the Adriatic (CETINIĆ et al., 1999).

The Fishing Fleet Register of Croatia currently includes 7733 vessels (DF, 2015). All national reports for period before 2014 indicate the number of around 4400 vessels (of which 3360 vessels are less than $12 \mathrm{~m}$ indicating their small-scale character) and around 11000 vessels registered under subsistence category. This discrepancy is the consequence of inclusion of 3500 vessels (small coastal fishery) in the fleet register following the accession negotiations. The remaining number of fishermen either joined the recreational category of fisheries or became inactive as many of those licence holders neither were full-time fishermen, nor do they depend on fishing activity and only perform it in very specific places and in very specific times. Due to prolonged administrative and legislative procedure, the transition process of their full registration ended only in April 2015. The largest percentage of the fleet (over $90 \%$ ) is com- prised of vessels less than $12 \mathrm{~m}$ LoA (Length over All), which also constitute the largest segment of the fleet capacity in terms of power (some $60 \% \mathrm{~kW}$ ). The bulk of total tonnage of Croatian fishing fleet refers to purse-seiners, while multipurpose vessels comprise the most important part of total power. The purse-seiners fleet contained 375 vessels $(8.1 \%$ with LoA > than $12 \mathrm{~m}$ ) while bottom trawlers account for some $17 \%$ of the fleet. The largest number of vessels is registered as multipurpose vess $21 \mathrm{~s}$ (over $45 \%$ ) where fishermen target assemblages rather than species and where gears are changed several times over a year (DF, 2015).

Total Croatian catches reported in 2014 amounted to almost $80.000,00$ tons. By far, the largest percentage of the catch is realized by purse seines $(>90 \%)$. Towed gears account for some $8 \%$ of the catch. In terms of multipurpose vessels, driftnets and fixed nets (DFO) represent the majority of the values. However, their share in total landings is small, and accounts for less than $1 \%$. Their actual activity is highly seasonal. Only fixed nets are used in Croatia (gillnets and trammel nets), and they operate in shore and coastal waters, in limited areas and during limited periods. They landed mostly sole, Solea solea $(21 \%)$ and a mixture of other demersal species (hake, cuttlefish, sea breams, common octopus, etc.). Percentages for other fishing gears are less than $1 \%$ in the total catch. Landings in 2014 included 109 species in total. Majority of the landings of purse seines included sardine $(80 \%)$ and anchovies $(11 \%)$. Out of the total catch, fish represent $96 \%$, cephalopods about $2 \%$, crustaceans and shellfish also about $2 \%$ each (DF, 2015).

Data on the number of fishers are under evaluation, and taking into account the data from the crafts and commercial registry, and data on the number of crew and the number of licenses (vessels) in the fishing fleet, it is estimated that the sector directly employs around 11.000 people while around 7000 fishermen are involved in SSF sector. The highest number of SSF fishers $(>1200)$ is from regional units of Zadar, Split and Dubrovnik. In addition to fulltime employees, there are a significant number 
of seasonal workers but they are not present at SSF. Usually, there are just one or two fishers work on vessels $<12 \mathrm{~m}$ (mainly the owner and the close family member), while on average 3 and 8 fishers are employed on bottom trawlers and purse seiners, respectively.

In Croatia, shellfish are collected by hydraulic dredge - rapido trawl ("rampon" in Istra county) and by SCUBA diving in other parts of the coastal areas (VRGOČ et al., 2009). Due to small catch quantities, this group of marine organisms was not included in DCF and there is limited data on their distribution and catches. According to the Assessment of demersal fish and shellfish stocks commercially exploited in Croatia (VRGOČ et al., 2009), most important species are Mediterranean mussel (Mytilus galloprovincialis), European flat oyster (Ostrea edulis), Mediterranean scallop (Pecten jacobaeus), Warty venus (Venus verrucosa), smooth clam (Callista chione), Noah's ark shell (Arca noae), grooved carpet shell (Ruditapes decussatus), and baby clam (Chamelea gallina).

\section{Montenegro}

Legal framework in Montenegro recognizes small-scale (commercial) fisheries, which differ from large-scale fisheries in vessel size, type and number of fishing gears permitted and defines it as commercial fishing using a vessel of up to $12 \mathrm{~m}$ length overall (LOA) with fishing gear allowed for SSF: gillnets and trammel nets, fish pots and traps, harpoons, longlines, hooks and beach seines (IKICA et al., 2013; PEŠIĆ et al., 2016). Up to 180 licenses can be issued for small-scale commercial fishing. During the first half of 2016 in Montenegro, there was a total of 140 licensed fishing vessels for commercial fisheries. The largest percentage of the fleet is comprised of vessels less than $12 \mathrm{~m} \mathrm{LoA}(83 \%)$, of which $49 \%$ are vessels less than $6 \mathrm{~m} \mathrm{LoA}$. Vessels below 12 $\mathrm{m}$ LoA comprise about $34 \%$ of the fleet capacity in terms of power. Around $71 \%$ of all vessels in the fleet would fall under the SSF category, with trawlers represented by $16 \%$ and purse seiners by $12 \%$ of all vessels. A total of $17 \%$ of the fleet is made of vessels of over $12 \mathrm{~m} \mathrm{LoA}$. Multipurpose vessels represented approximately $53 \%$ of the fleet, with gillnetters and bottom trawlers coming up second, with $15 \%$ each. Trammel netters and beach seiners were represented by $6 \%$ each while purse seiners comprised $5 \%$. There is only limited data available on the size and catch of the current small-scale fishing fleet. The number of licensed SSF vessels (90 in 2015, 100 in 2016) represents only a part of the total fleet, and apart from some estimations, poor data on small-scale fishing fleet catch are available, both regarding the catch in weight and catch composition. In total, $63 \%$ vessels in the fleet could be considered as multipurpose (polyvalent) vessels. Gillnets are the most common type of fishing gear used in small-scale fisheries, followed closely by trammel nets and beach seines targeting pilchard (Sardina pilchar$d u s$ ) and anchovy (Engraulis encrasicolus). In Montenegro, the shellfish fishing is regulated by the Law on Marine Fisheries and Mariculture (OFFICIAL GAZETTE OF MONTENEGRO, No. $56 / 09$ and 47/2015) by which is allowed to collect edible shellfish tools manually, without the use of dredges. Each year, there is a possibility for issuing a total of 5 licenses for manually collecting shellfish, of which in 2015 were issued only 3 , and allowed quantity of harvest is 1 tones per license. The license does not define the shellfish species that can be harvested. There is no data available on the amount of the annual catch, or catch by species.

This review study represents integrated and comparable approach between Croatia and Montenegro to investigate the state and perspective of SSF on the eastern Adriatic coast. Different alternatives are proposed to modify the strategies of management and research in order to achieve sustainable exploitation of coastal resources. Thus, this paper includes a number of aspects in order to obtain better insight into the structure of SSF activities in the Croatia and Montenegro. We will present current fishing effort, qualitative and quantitative catch composition, characteristics and distribution of target species and exploitation levels. And finally, as a result of the above, preparation of recommendations for protection, sustainable use and management of coastal resources on the eastern 
coast, and the Adriatic sea as a whole, especially in view of the guidelines of Regulation of the European Union which must be accepted by member states, but also in Montenegro, as country which is in the pre-accession negotiations.

\section{MATERIALS AND METHODS}

\section{Study area}

The Adriatic Sea is a semi-closed, elongated basin of the central Mediterranean Sea and, because it is set deeply into the land mass and is of low depth, it can be considered a closed, inland sea. The Adriatic is connected to the other parts of the Mediterranean basin through the Strait of Otranto. The length of the Adriatic Sea is approximately $870 \mathrm{~km}$, and the width ranged from 90 to $220 \mathrm{~km}$. Its area, including the islands, is $138,595 \mathrm{~km} 2$, which is approximately $4.6 \%$ of the total area of the Mediterranean Sea. Practically, the Adriatic Sea is usually divided into North, Central and Southern Adriatic. The geomorphological characteristics of the Adriatic basin, the geopolitical changes

\section{(a) Croatia}

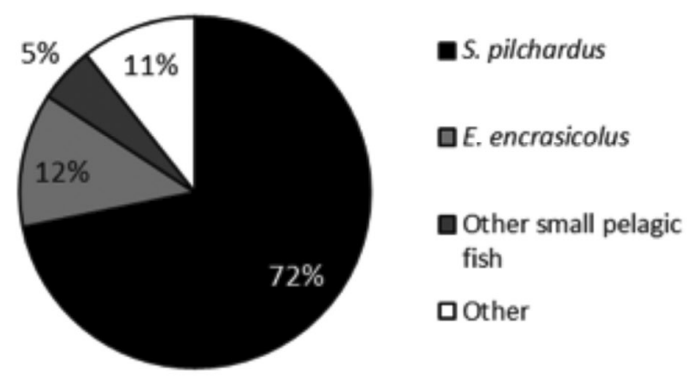

(b) Croatia

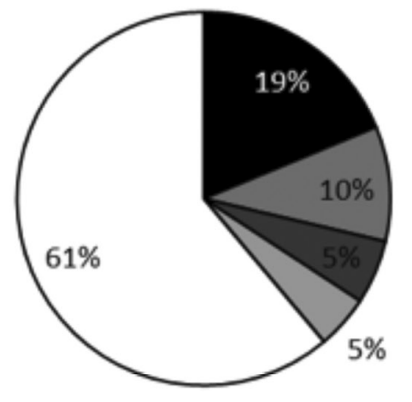

on its eastern seaboard, the existence of national statistics directorates, and the distribution of fishery resources have led to the division of the Adriatic area into two Geographical Sub-Areas: GSA 17 (North and Central Adriatic) shared by Italy, Croatia, Slovenia, and Bosnia and Herzegovina; and GSA 18 (South Adriatic) shared by Croatia, Montenegro, Albania, and Italy. The western coast of GSA 17 is flat and mostly sandy, whereas the eastern coast and the western coast of GSA 18 is generally steep and rocky, including sensitive marine habitats as seagrass meadows and coralligenous habitats (GRATI et al., 2013). The central and northern Adriatic Sea has an extended continental shelf and eutrophic shallow waters, whereas a narrow continental shelf and a marked, steep continental slope characterize the southern Adriatic. The basic inflow of nutrients into the Adriatic occurs via the rivers that raise the primary productivity. Eutrophication is particularly pronounced in the northern Adriatic, where it influences primary production and ultimately leads to higher landings quantities, allowing to this part to become one of the most productive areas of the Mediterranean

Fig. 1. Landing composition of the total landings (a) and small-scale fisheries landings (b) for Croatia and Montenegro (2013).

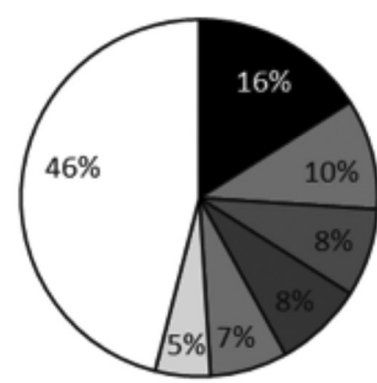

(a) Montenegro

$$
\text { -S. pilchardus }
$$

$\square$ E. encrasicolus

口. merluccius

-5. sarda

口M. barbatus

口. longirostris

口other

(b) Montenegro

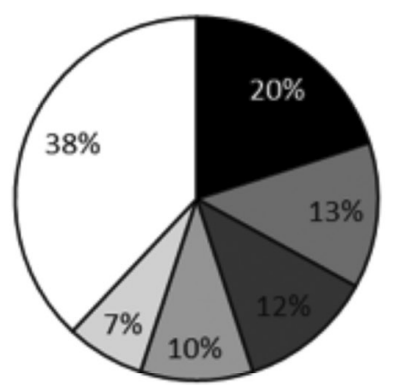

- s. pilchardus

$\square$ E. encrasicolus

as. sarda

$\square C$. conger

$\square$ P. pagrus

口Other 
in terms of fisheries. Due to the pronounced seasonal fluctuations in environmental forcing, coastal waters show a high seasonal variation in sea temperature, ranging from $7^{\circ} \mathrm{C}$ (winter) to $27^{\circ} \mathrm{C}$ (summer). Prevailing currents flow counterclockwise from the Strait of Otranto, along the eastern coast and back to the Strait along the Italian coast (Fig. 1). According to productivity, the Adriatic Sea is classified as an oligotrophic sea, characterized by relatively low productivity. In the present study, data for SSFs operating on the eastern Adriatic coast, in the national waters of Croatia and Montenegro are taking into account.

\section{Data collection}

The aim of the present study was to collect the best available data on SSFs in order to assess the seasonality of used fishing gears and target species catches in the Croatia and Montenegro. On this basis, all the potential data sources have been considered in the study: Data Collection Framework (DCF) and statistical data from Croatian Fisheries Directorate for Croatia and statistical data from Montenegrin Fisheries Directorate.

In order to assess the seasonality of the fishing activity, we agreed to focus on the most common fishing gears used: gill nets, trammel nets, traps and longlines by estimating catch composition, landings biomass and monthly fishing effort for each fishing gear in 2013.

\section{Data analysis}

Monthly data concerning landings $(\mathrm{kg})$ and fishing effort (days at sea) from the small-scale fisheries in 2013 in Croatia were obtained from statistical reports of the Fisheries Department and Fleet Register. In Montenegro, the total data were obtained from Montenegrin Fisheries Directorate and are based on the estimations based on the landing data provided by fishermen. Croatian data are presented according to seven regional units (Dubrovnik, Split, Šibenik, Zadar, Senj, Rijeka and Pula) while Montenegrin data are divided by eight main landing places (Bar, Budva, Herceg Novi, Kotor, Petrovac, Tivat, Ulcinj and Zelenika). The nominal LPUE (Landing Per Unit Effort) of each fishing gear was calculated by dividing total landing by the number of fishing days. Basic statistics in Excel were performed.

\section{RESULTS}

\section{Total landings}

The total landings of Croatia was 74.935,325 tons in 2013 and the vast of the catch was realized by purse seins and towed gears (about 98 $\%)$. Percentages for other gears were less than $1 \%$ in the total catch. The largest part of the catch was represented by small pelagic fish, Sardina pilchardus (72\% in total catch) followed by Engraulis encrasicolus (12\%) and other small pelagic fish (5\%). According to landings data presented in Table 1. total catch of SSF was 1,101 tonnes. The total catch of Montenegro amounted to 534.67 tons. Most of the catch came from bottom trawls landings (35\%). Purse seine catches comprised around $25 \%$ of the total catch, followed by beach seines (20\%), gill- and trammel nets $(10 \%)$ and longlines $(8 \%)$. There-

Table 1. CPUE for different fishing gears in Croatia

\begin{tabular}{lccccc}
$\begin{array}{l}\text { Fishing gears } \\
\text { (number of } \\
\text { licences) }\end{array}$ & Total landing & $\begin{array}{c}\text { Total fishing } \\
\text { effort }\end{array}$ & $\begin{array}{c}\text { Average landing } \\
\text { (SD) }\end{array}$ & $\begin{array}{c}\text { Average fishing } \\
\text { effort (SD) }\end{array}$ & $\begin{array}{c}\text { Average CPUE } \\
\text { (SD) }\end{array}$ \\
\hline GNS (1331) & $409,472.5$ & 41,115 & $307.41(52.29)$ & $30.86(14.21)$ & $11.49(2.04)$ \\
GTR (1247) & $391,938.04$ & 29,918 & $314.3(159.62)$ & $23.99(5.15)$ & $12.76(3.94)$ \\
LLD (633) & $196,045.36$ & 8,858 & $309.71(216.90)$ & $13.99(3.10)$ & $14.73(6.13)$ \\
LLS (10) & $7,665.5$ & 142 & $766.55(605.86)$ & $14.2(4.36)$ & $47.7(8.96)$ \\
FPO (513) & $96,944.55$ & 11,988 & $341.52(86.31)$ & $23.37(10.45)$ & $11.55(7.13)$
\end{tabular}


Maті́́-Sкоко et. al.: A comparative approach to the Croatian and Montenegrin small-scale fisheries (SSF) ... 465

Table 2. Number of vessels (active licenses) according to vessel length and regional units in Croatia.

\begin{tabular}{|c|c|c|c|c|c|c|c|}
\hline LOA $(\mathrm{m})$ & Dubrovnik & Split & Šibenik & Zadar & Senj & Rijeka & Pula \\
\hline$<3$ & - & 4 & - & - & - & - & - \\
\hline 4 & 7 & 14 & 1 & 4 & 1 & 20 & 10 \\
\hline 5 & 79 & 94 & 41 & 60 & 14 & 104 & 181 \\
\hline 6 & 115 & 79 & 33 & 77 & 14 & 59 & 98 \\
\hline 7 & 154 & 194 & 69 & 152 & 34 & 150 & 119 \\
\hline 8 & 82 & 152 & 61 & 108 & 31 & 170 & 128 \\
\hline 9 & 34 & 108 & 50 & 69 & 13 & 61 & 97 \\
\hline 10 & 23 & 53 & 25 & 33 & 9 & 45 & 62 \\
\hline 11 & - & 20 & 6 & 29 & 3 & 20 & 71 \\
\hline 12 & 2 & 5 & 8 & 15 & 4 & 20 & 52 \\
\hline 13 & - & - & 8 & 1 & 3 & 4 & 27 \\
\hline 14 & - & 3 & - & - & - & 5 & 13 \\
\hline 15 & - & 1 & - & 6 & - & - & 8 \\
\hline 16 & - & - & - & - & - & - & - \\
\hline 17 & - & - & - & - & - & - & 1 \\
\hline 18 & - & - & 1 & 1 & - & - & 1 \\
\hline 19 & - & - & - & - & - & - & - \\
\hline 20 & - & 727 & 303 & 555 & 126 & 658 & 869 \\
\hline TOTAL & - & - & - & - & - & - & -1 \\
\hline
\end{tabular}

fore, the estimated landings per SSF are around 203 tons. Most important species in the total catch were also $S$. pilchardus and E. encrasicolus (26\% of total catch) (Fig 1a).

Most of the Croatian SSF landings come from gillnets (37.0\%) and trammel nets $(36.0 \%)$, followed by set longlines $(17.0 \%)$, traps $(9.0 \%)$ and drift longlines (1.0\%). On the other side, in Montenegro most of the SSF catches were landed by beach seines (52\%), gill- and trammel nets $(27 \%)$ and set longlines $(21 \%)$. In Croatia, common sole, Solea solea represented largest part of the landing biomass (19\%) accomplished by fishing gears used by SSF, followed by the hake, Merluccius merluccius (10\%) and octopus, Octopus vulgaris (6\%). Other species in total landings (104) corresponding to $61 \%$ of the total catch in term $\mathrm{f}$ abundance. However, in term of landing biomass those species were presented less than $5 \%$. In Montenegro, S. pilchardus and E. encrasicolus were also the most dominant species in the catch of SSF (33\%), together with atlantic bonito, Sarda sarda, Euro- pean conger, Conger conger, red porgy, Pagrus pagrus, bullet tuna, Auxis rochei and round sardinella, Sardinella aurita. All other fish species (20) corresponding to $38 \%$ of the total catch in term of abundance, but each species was represented under 5\% in landing biomass (Fig. 1b).

\section{Fishing licences}

Total number of registered licenses for gillnets, trammel nets, traps, set longlines and drift longlines in Croatia for 2013 were 11,450 of which 3,734 were active and 7,716 inactive licenses. Pula have the greatest number of registered licenses (869) followed by Split (727) and Rijeka (658) while Senj had lowest number of registered licenses (126) (Table 2). Vessels with the length overall bellow $12 \mathrm{~m}$ were represented by around $98 \%$ while others were larger than 12 $\mathrm{m}(2 \%)$.

There were a total of 118 licenced fishing vessels in the Montenegrin fleet with 273 employed fishers in 2013 for SSF. This number of employees is far from realistic, as there were 
Table 3. Number of vessels registered for small-scale fisheries according to vessel lenth and by port (MARD) in Montenegro

\begin{tabular}{|c|c|c|c|c|c|c|c|c|}
\hline \multicolumn{9}{|c|}{ PORT } \\
\hline LOA $(\mathrm{m})$ & Bar & Budva & H. Novi & Kotor & Petrovac & Tivat & Ulcinj & Zelenika \\
\hline$\leq 3$ & 0 & 0 & 0 & 1 & 0 & 2 & 0 & 0 \\
\hline 4 & 0 & 3 & 3 & 11 & 1 & 2 & 9 & 5 \\
\hline 5 & 2 & 4 & 3 & 5 & 0 & 3 & 1 & 1 \\
\hline 6 & 6 & 1 & 3 & 3 & 1 & 0 & 1 & 0 \\
\hline 7 & 1 & 3 & 3 & 0 & 0 & 2 & 0 & 2 \\
\hline 8 & 1 & 0 & 0 & 1 & 0 & 1 & 0 & 1 \\
\hline$\geq 9$ & 1 & 1 & 0 & 0 & 0 & 1 & 0 & 0 \\
\hline TOTAL & 11 & 12 & 12 & 21 & 2 & 11 & 11 & 9 \\
\hline
\end{tabular}

many unreported workers engaged in the fisheries. The total number of vessels registered for SSF by port and length overall in Montenegro is presented in Table 3. Kotor has the greatest number of registered vessels (21), while Petrovac has only two registered vessels.

In Croatia most of these vessels were equipped with more than one type of fishing gear during the year depending when the target species concentrate inside the coastal areas during the recruitment or the spawning season. Gillnets and trammel nets were the most commonly used fishing gears represented by $35.6 \%$ and $33.4 \%$ respectively (in total 69\%) followed by set longlines (17.0\% (633), traps with $13.7 \%$ (513) and drift longlines with $0.3 \%$ (10) of the total active licenses (Fig. 2, Table 4).

As shown in Table 4, there were 7,716 inactive licenses. According to the regional units, Pula had the greatest number of inactive licenses
$(2,473)$, followed by Split $(1,479)$ and Zadar $(1,221)$ while Senj (191) had lowest number of inactive licenses. According to the type of gear, traps were represented with 2,328 licenses, followed by trammel nets with 1,985 and set longlines with 1,842 licenses.

Most of the SSF vessels in Montenegro (63\%) use more than one type of fishing gear. The single-gear vessels from use mostly gillnets (18\% of total fleet), trammel nets $(11 \%)$, and beach seines (7\%). In general, gillnets and trammel nets are the most widely used fishing gears in small-scale fisheries (65\%) (Fig. 2), followed by beach seine nets $(14 \%)$. Longlines, both set and drift ones, are represented by about $10 \%$ each.

Fishing gears used by SSFs per each country are divided according to the target species and mesh size (Table 5). In general, both countries have the similar minimum mesh sizes for
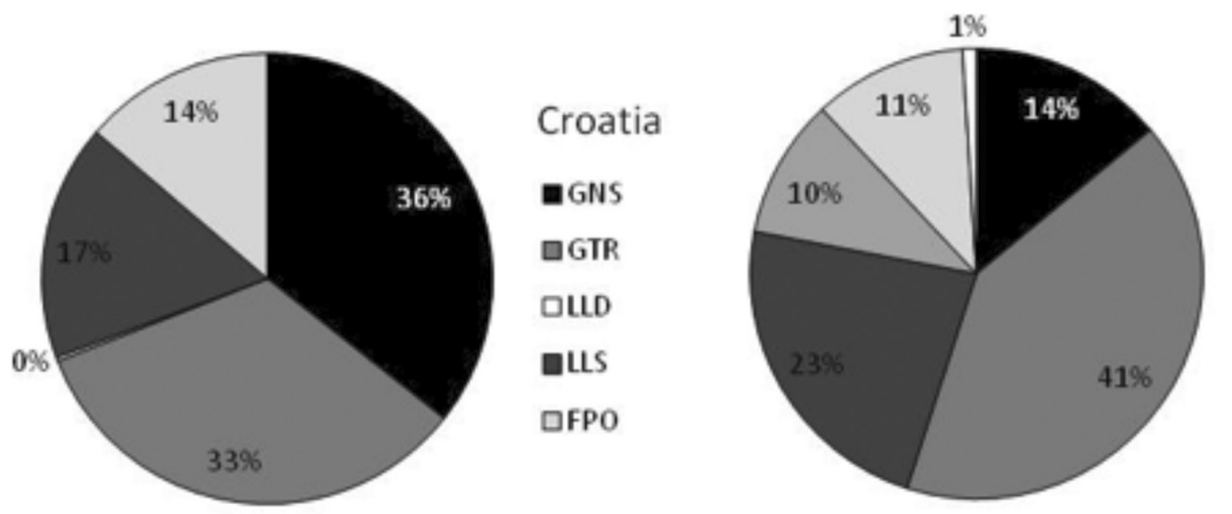

Montenegro

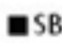

a GNS

aGTR

口LD

口us

-Harpoon/spear

Fig. 2. Distribution of active licenses for each type of fishing gear in Croatia and Montenegro. 
MAтіĆ-Sкоко et. al.: A comparative approach to the Croatian and Montenegrin small-scale fisheries (SSF) ... 467

Table 4. Number of active and inactive licenses according to the regional units and type of gear.

\begin{tabular}{|c|c|c|c|c|c|c|c|c|}
\hline Gear & Dubrovnik & Split & Šibenik & Zadar & Senj & Rijeka & Pula & TOTAL \\
\hline GNS & $193(94)$ & $261(299)$ & $121(100)$ & $187(270)$ & $48(32)$ & $228(246)$ & $293(481)$ & $1331(1522)$ \\
\hline GTR & $153(176)$ & $178(395)$ & $69(103)$ & $208(349)$ & $34(38)$ & $150(223)$ & $455(701)$ & $1247(1985)$ \\
\hline LLD & $4(2)$ & $-(7)$ & $3(20)$ & $3(4)$ & - & $-(2)$ & $-(4)$ & $10(39)$ \\
\hline LLS & $81(160)$ & $192(297)$ & $64(152)$ & $87(327)$ & $16(52)$ & $125(286)$ & $68(568)$ & $633(1842)$ \\
\hline FPO & $65(236$ & $96(481)$ & $46(223)$ & $70(271)$ & $28(69)$ & $155(329)$ & $53(719)$ & $513(2328)$ \\
\hline TOTAL & $496(668)$ & $727(1479)$ & $303(598)$ & $555(1221)$ & $126(191)$ & $658(1086)$ & $869(2473)$ & $3734(7716)$ \\
\hline
\end{tabular}

Table 5. The difference between type of fishing gears according to the target species and mesh size (bar length)

\begin{tabular}{|c|c|c|}
\hline GILLNET & $\mathrm{CRO}$ & MNE \\
\hline for big-scale sand smelt ("oližnica") & $10-18$ & - \\
\hline for sand smelt ("gavunara") & 20 & 20 \\
\hline for picarel ("girara") & 30 & 30 \\
\hline for blotched picarel ("menulara") & $36-40$ & $32-40$ \\
\hline for small pelagic fish ("vojga") & $32-40$ & 32 \\
\hline for bogue ("bukvara") & 56 & $40-52$ \\
\hline for demersal fish ("prostica") & 64 & 56 \\
\hline for atlantic bonito & 80 & 80 \\
\hline for sharks ("psara") & 120 & 120 \\
\hline for lobsters (“jastogara”) & 240 & - \\
\hline for rays and crabs ("sklatara") & 260 & $80 / 300^{*}$ \\
\hline \multicolumn{3}{|l|}{ TRAMMEL NET } \\
\hline for cuttlefish (,,sipara“) & $64 / 300 * *$ & \\
\hline trammel net (,„popunica“) & $80 / 300 * *$ & $56 / * * *$ \\
\hline for common sole („listarica“) & $80 / 300 * *$ & $72 / * * *$ \\
\hline for salema (,,salpara“) & $80 / 300 * *$ & $80 / * * *$ \\
\hline for turbot (,rumbara“) & $240 / 700 * *$ & \\
\hline \multicolumn{3}{|l|}{ TRAPS $* * *$} \\
\hline for demersal fish & 32 & 32 \\
\hline for lobsters & 55 & 55 \\
\hline for Norway lobster & $18-20$ & 18 \\
\hline for european eel & 12 & \\
\hline
\end{tabular}

* In Montenegro gillnet for rays has mesh size $80 \mathrm{~mm}$ and gillnet for crabs has mesh size $300 \mathrm{~mm}$.

** inner/ outer layer

*** In Montenegro, the minimum size of external mesh size for trammel nets are not defined.

gillnets with exception of gillnets intended for catching big crabs and rays that is separated in Montenegro. Regarding trammel nets, minimum mesh size is greater in "poponica" and "listara" used in Croatia. Also, outer layer mesh size of trammel nets is not defined in Montenegro. Also, special constructive measures for traps not exist in Montenegro. The constructive measures for traps are practically identical in the two countries.

The gill nets have the highest and set longlines the lowest total fishing effort in Croatia (Table 1). Further on, the average fishing effort is also highest for gillnets following with 
(a) Croatia
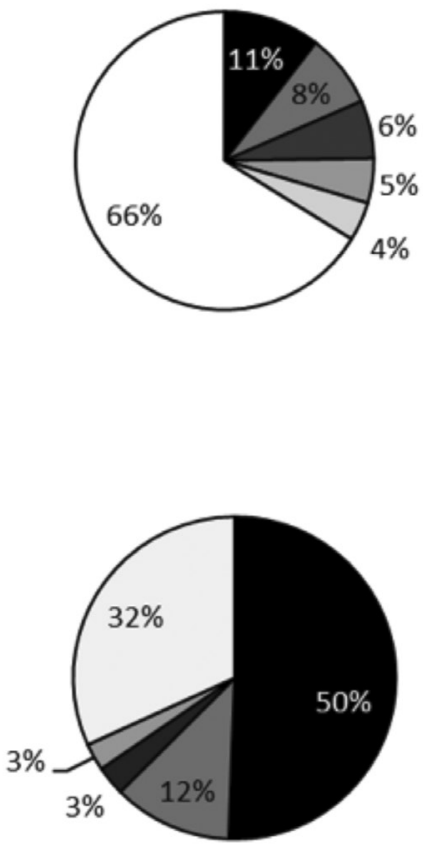

-M. merluccius

口S. surata

- Liza sp.

口M. squinado

ㅁ. boops

口other (b) Croatia

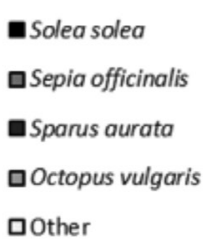

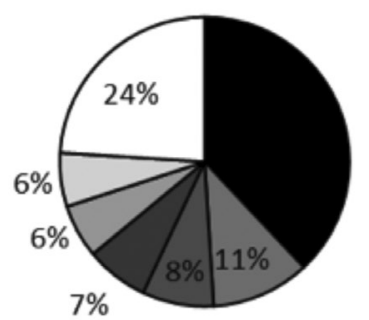

(a) Montenegro

-s. sarda

$\square$ P. erythrinus

口S. dumerilii

口. japonicus

$\square$ Triglidae sp.

口S. salpa

口Other

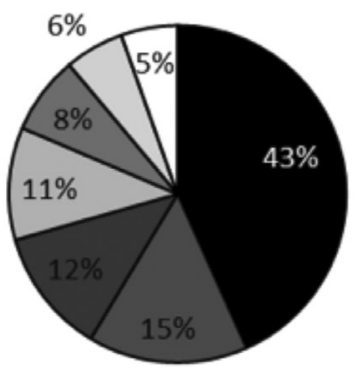

(b) Montenegro

- S. sardo

口M. barbatus

口S. dumerilii

$\square$ A. rochei

口S. officinalis

口M. merluccius

口Other

Fig. 3. Landing composition of the gillnets (a) and trammel nets (b) in Croatia and Montenegro.

trammel nets and pots. However, average CPUE is highest for set longlines following by drift longlines and trammel nets. Due to the lack of systematic data collection on fishing effort, no reliable data on CPUE are available in Montenegro at this moment.

\section{Gillnets}

The landing composition of Croatian gillnets was dominated by the three species: hake (Merluccius merluccius, $10.5 \%$ ), gilthead sea- bream (Sparus aurata, $8 \%$ ) and mullets (Liza spp, $6.3 \%$ ). Other species contributed to the landing composition with a less than 5\% (Fig. 3a). Atlantic bonito (Sarda sarda) appeared as the dominant species in catch in Montenegro (38\%). Other significant species in the catch were common pandora (Pagellus erythrinus, $11 \%$ ), greater amberjack (Seriola dumerilii, 6\%), chub mackerel (Scomber japonicus, 7\%), gurnard (Triglidae sp., 6\%), and salema (Sarpa salpa, 6\%). All other species were represented
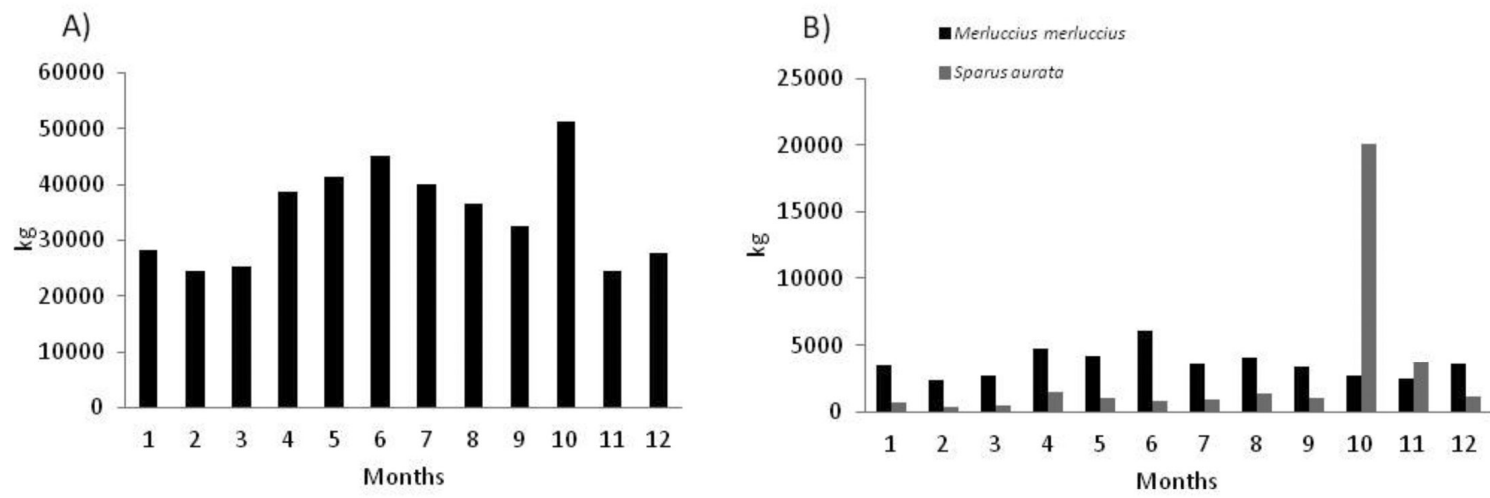

Fig. 4. Monthly fluctuation of total biomass (A) and biomass of target species (B) for gillnets landings in Croatia (2013). 

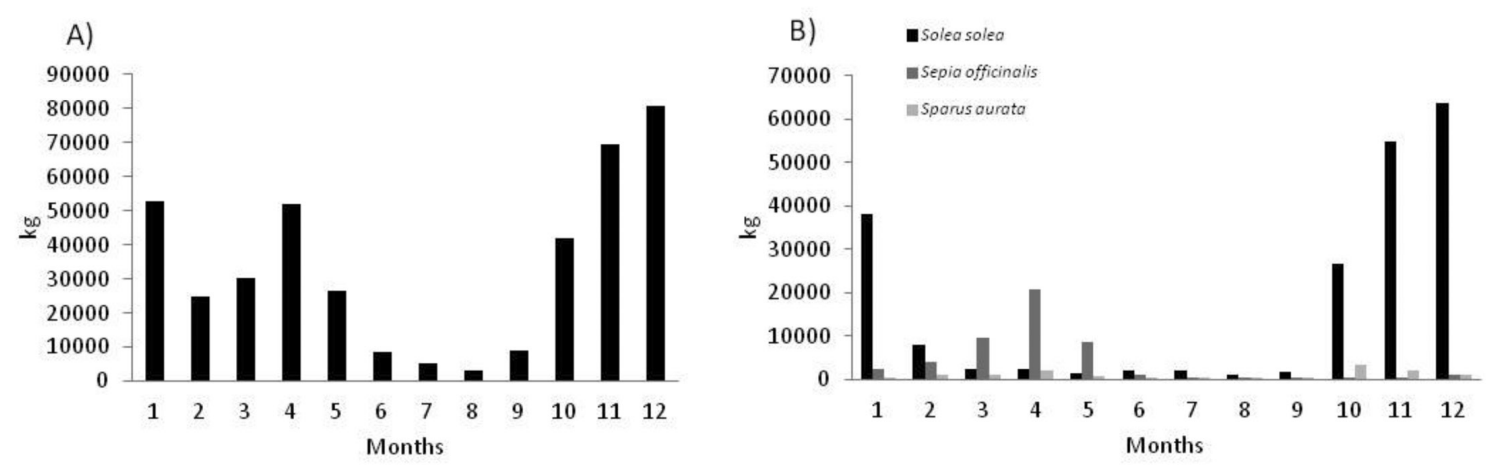

Fig. 5. Monthly fluctuation of total biomass (A) and biomass of target species (B) for trammel nets landings in Croatia (2013).

with less than $5 \%$ in the total gillnet catch, and together amounted to $24 \%$ (Fig. 3a).

Total catch accomplished by gillnets in 2013 (Croatia) were $416,150 \mathrm{~kg}$. With respect to months, highest catch was registered in October $(51,347 \mathrm{~kg})$ due to seasonal catch of gilthead seabream, Sparus aurata and the lowest one was in February (24,524 kg) (Fig. 5A). Total estimated catch of gillnets in Montenegro was 73,010 $\mathrm{kg}$. Unfortunately, monthly values for gillnet landings are not available for this country. In Croatia, gillnets were used to catch M. merluccius all year round with the highest monthly catch in June $(6,053 \mathrm{~kg})$ and the lowest one in February $(2,394 \mathrm{~kg})$. During the rest of the year, monthly landing biomass values of hake were around 3,000-4,500 kg. Landing of gilthead seabream showed a more distinct seasonality with landings almost exclusively accomplished in October $(20.048 \mathrm{~kg})$ and the lowest catches in February $(443 \mathrm{~kg}$ ). During other seasons, catches of $S$. aurata remained near $1,000 \mathrm{~kg}$ per month (Fig. 4B).

\section{Trammel nets}

The landing composition of trammel nets in Croatia was dominated by the common sole (Solea solea; 50\%), and followed by the cuttlefish (Sepia officinalis, 12\%) while other species contributed to the total landings with a fraction lower than 3\% (Fig. 3b). Similar to gillnet catches, Atlantic bonito (Sarda sarda) was the dominant species in Montenegrin trammel nets
(44\%). Other species with significant share in the catch were red mullet (Mullus barbatus, $15 \%$ ), greater amberjack (Seriola dumerilii, $12 \%$ ), bullet tuna (Auxis rochei, 11\%), common cuttlefish (Sepia officinalis, 7\%), and European hake (Merluccius merluccius, 6\%). The contribution of all other species together in total catch was less than $5 \%$.

In Croatia, the landing biomass showed the highest values during fall-winter for the common sole and during winter-spring period for cuttlefish. Total landings in Croatia was 404,780 $\mathrm{kg}$ with the highest value in December $(80,967$ $\mathrm{kg}$ ) and the lowest one in August $(2,993 \mathrm{~kg}$ ) (Fig. 5A). The total catch for Montenegrin trammel nets in 2013 was estimated at $9,390 \mathrm{~kg}$. Unfortunately, monthly trammel net catch statistics are not available for Montenegro. In Croatia, landing biomass of the common sole was the highest in fall and early winter with a peak in December $(63,785 \mathrm{~kg})$, during the spawning season of this species. During the rest of the year, landings showed subsequent decrease in the following months with the lowest catch in August $(1,119 \mathrm{~kg})$. The landings of cuttlefish were mainly concentrated in spring, with the maximum value of $20,579 \mathrm{~kg}$ in April while the lowest landings were reported in summer (June and July). Biomass of gilthead seabream landed by trammel nets showed similar seasonality in catch like in gillnets. Highest landing was recorded in October $(3,204 \mathrm{~kg})$ and after that landings decreased through winter and spring period with another peak in April $(1,939 \mathrm{~kg})$. 
The lowest landing biomass of $S$. aurata was reported in August (41 kg) (Fig. 5B).

\section{Traps}

The octopus (Octopus vulgaris) was dominant species (44\%) in the trap's landings in Croatia, followed by the Norway lobster (Neprophs norvegicus; $21 \%$ ). Other species individually contributed to the total landings accomplished by traps with a fraction lower than 10\% (Fig. 6).

In 2013, total catch using traps were 100,835 $\mathrm{kg}$ with highest landing biomass during the late spring and summer with a peak in June $(15,706$ $\mathrm{kg}$ ) (Fig. 7A) while lowest catches were recorded for February. A peak in late spring-summer season was achieved due catches of the Norway lobster in August $(3,102 \mathrm{~kg})$ and owing to the high landings of the octopus in June $(5,066 \mathrm{~kg}$; Fig. 7B).

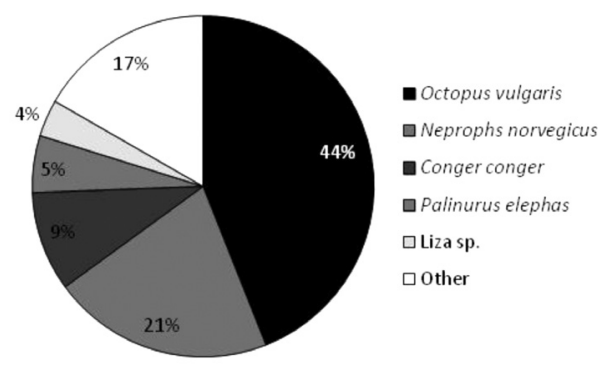

Fig.6. Landing composition of the traps in Croatia.

\section{Drift longlines}

In Croatia, the landing composition accomplished by the drift longlines was dominated by the swordfish (Xiphias gladius; 63\%), alba-

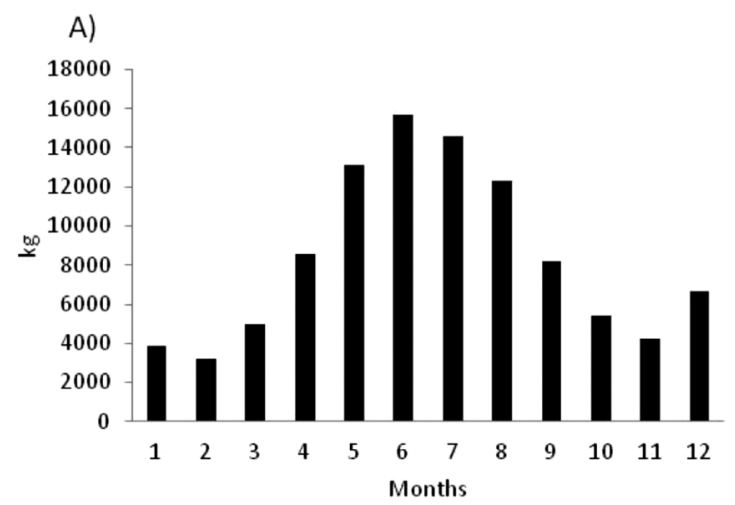

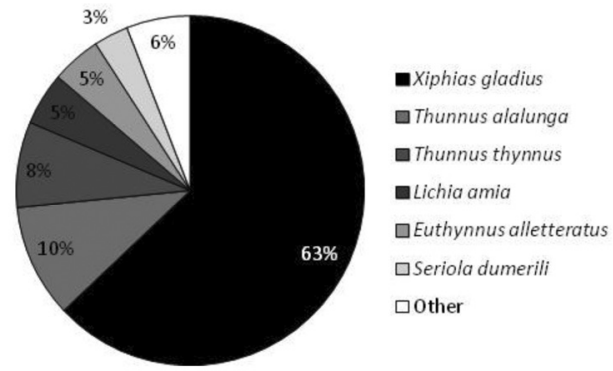

Fig. 8. Landing composition of the drift longlines in Croatia.

core (Thunnus alalunga; 10\%) and bluefin tuna (Thunnus thynnus; 8\%) (Fig. 8).

Total landing biomass using drift longlines were $7,906 \mathrm{~kg}$ with highest landings in late spring and summer $(2,061 \mathrm{~kg}$ were recorded in July) with additional one peak in December (1,076 kg) (Fig. 9A). Particularly, the swordfish and albacore were mainly caught during the late spring and summer with a peak in August for the swordfish $(1,598 \mathrm{~kg})$ and July for the albacore (479 kg) (Fig. 9B).

\section{Set longlines}

In Croatia, the landing composition of set longlines was dominated by the hake (33\%), followed by the gurnards (Triglidae sp) that constituted $17 \%$ of landings and European conger (Conger conger) with 11\%, while other species contributed to the total landings with a fraction lower than 6\% (Fig. 10). In Montenegro, European conger (Conger conger) was the dominant species in the landings (47\%), followed by red porgy (Pagrus pagrus) (32\%), European hake

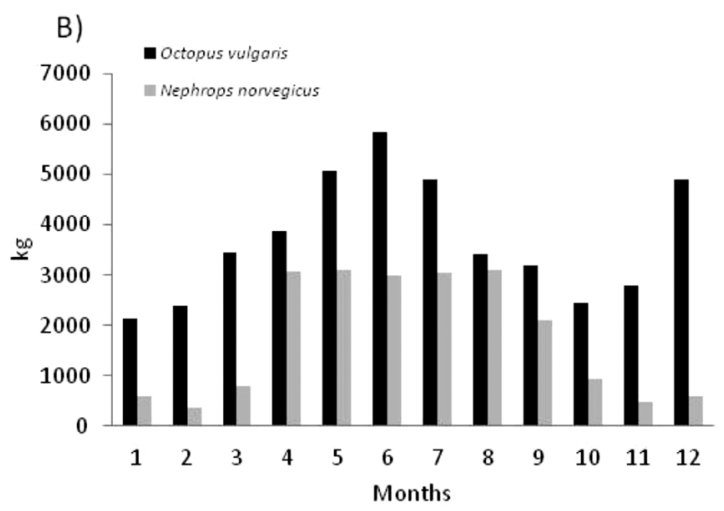

Fig. 7. Monthly fluctuation of total biomass (A) and biomass of target species (B) for traps landings in Croatia (2013). 

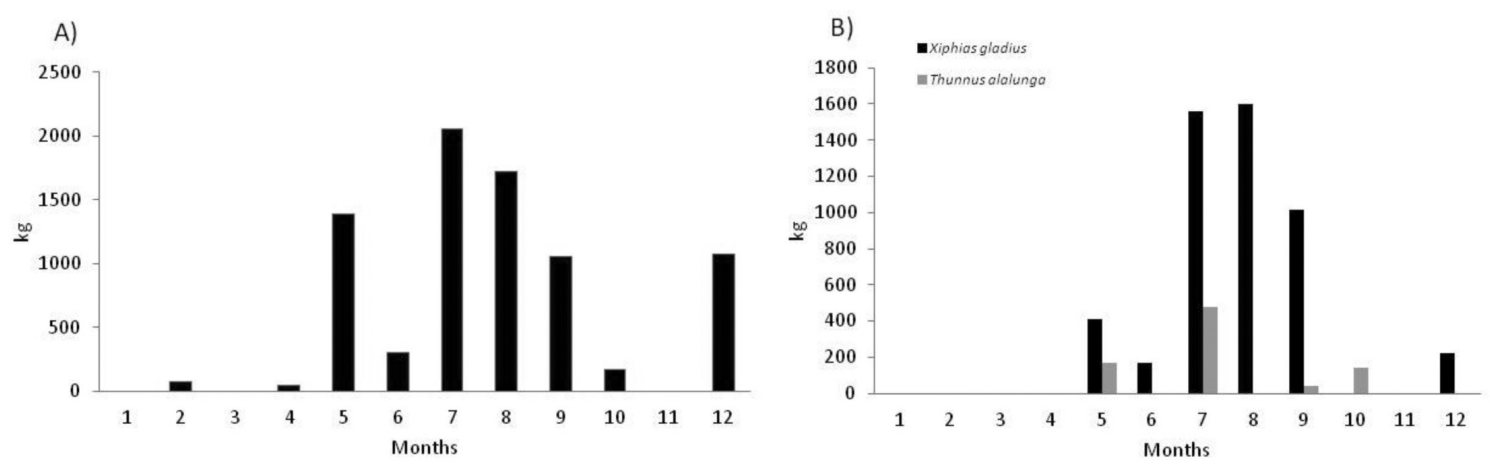

Fig. 9. Monthly fluctuation of total biomass (A) and biomass of target species (B) for drift longlines landings in Croatia (2013).

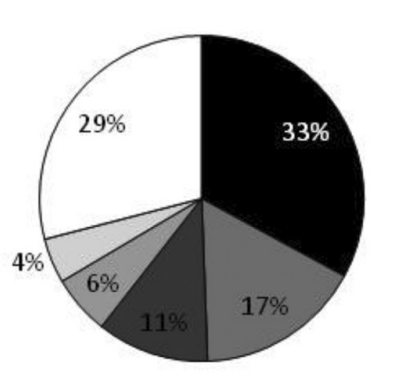

Croatia
Merluccius merluccius
घriglidae sp.
aConger conger
$\square$ Rajidae sp.
$\square$ Phycidae sp.
$\square$ Other

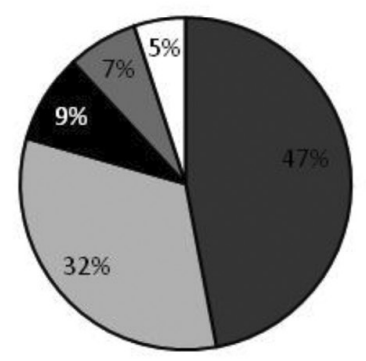

\author{
Montenegro \\ - Conger conger \\ 口Pagrus pagrus \\ - Merluccius merluccius \\ 口Triglidaesp. \\ 口other
}

Fig. 10. Landing composition of the set longlines in Croatia and Montenegro.
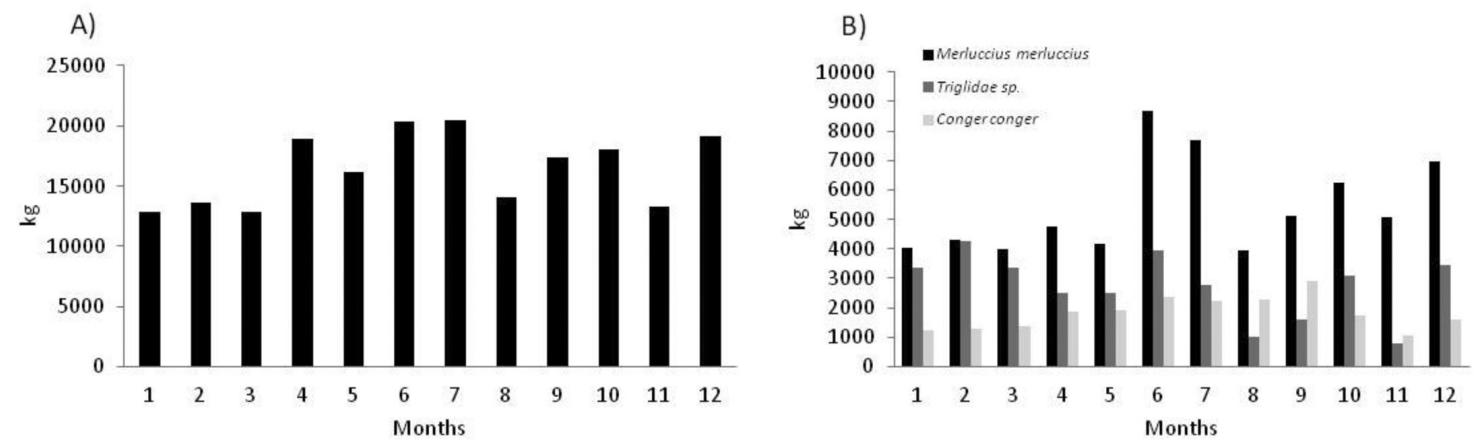

Fig. 11. Monthly fluctuation of total biomass (A) and biomass of target species (B) for set longlines landings in Croatia (2013).

(9\%) and gurnards (Triglidae spp.) (7\%), with all other species represented by about $5 \%$.

Total landing biomass using set longlines in Croatia was $197,326 \mathrm{~kg}$ with the similar landings during the whole year. However, the highest values were recorded in June $(20,408 \mathrm{~kg})$ and July $(20,439 \mathrm{~kg})$ and lowest ones in March $(12,836 \mathrm{~kg})$ and January $(12,907 \mathrm{~kg})$ (Fig. 11A). All dominant target species in set longlines were landed during the whole year, with highest landing peaks different for each species. The hake had the highest $(8,662 \mathrm{~kg})$ and lowest $(3,946 \mathrm{~kg})$ values of landings in June and August, respectively. The gurnards had a marked landings peaked in February $(4,251 \mathrm{~kg})$ and June $(3,952$ $\mathrm{kg}$ ). European conger was mainly landed during warmer part of the year with a peak in September $(2,924 \mathrm{~kg})$ (Fig. 11B). In Montenegro, the total estimated landings of set longline were 43,800 kg. No estimates for monthly landings are available. 


\section{DISCUSSION}

Croatian fisheries in general, and consequently SSF, is more significant in terms of the number of participants and the total landings within the Adriatic basin than Montenegrin. However, in both countries the percentage contribution of SSF fishers in total fisheries sector is $71 \%$. Such fact clearly pointed out that SSF is predominant type of fisheries on the eastern Adriatic coast. Further on, it's fully fit in Mediterranean fisheries context since much of the fishery in the Mediterranean coastal zone is SSF (80\%) (FARRUGIO et al., 1993; FARRUGIO, 1996). Official statistics of 1989-1990 for SSF suggests that in the EU countries operate 41,900 units, of which majority are registered in Greece, Italy, Spain and France (FARRUGIO, 1996). Beside these mentioned countries, Croatia also has a large SSF fleet in term of vessel units but it was not considering in this list prior to 2013 when it became the EU Member State. Small-scale fishers rotate fishing gears throughout the year not only in accordance with legislative regulations, but also to optimize yields, based on their knowledge of the behavior and catchability of target species, and they strongly depend on proximity to home harbor (particularly in winter period) and habitat heterogeneity (FORCADA et al., 2010). According to the national Croatian statistics, SSF landings contribute by only $1 \%$ (around $1,500 \mathrm{t}$ ) to the total landings. This contribution is for sure underestimated. According to Montenegrin statistics, almost $40 \%$ of landings originated from SSF (around $215 \mathrm{t}$ ). However, both values can be considered speculative due to unreliable data used for statistical analysis and numerous estimations in situations when direct data are not available. Further on, in the Mediterranean, in certain cases, the volume taken out by recreational fishing can be equal or even greater than that of commercial fishing (FONT \& LLORET, 2014). They suggested that the sum of catches in recreational fishing in the Mediterranean regions represents between $10 \%$ and $50 \%$ of the total haul of small-scale fishing (excluding trawls and seines). A total of $10 \%$ of adults living in developed countries practice recrea- tional fishing, which in the Mediterranean Sea represents around $10 \%$ of the total production of fisheries. Despite its importance, this fishing is not as controlled or studied as commercial ones. Also, the Mediterranean also has a notorious reputation for illegal fishing. Sometimes this is carried out under the guise of "sports fishing", the impact of which is considerable. In addition, due to the complex nature of national maritime boundaries and inadequate monitoring, control and enforcement, much illegal, unregulated and unreported (IUU) fishery activity takes place beyond national boundaries (LLORET et al., 2017).

At the EU level, there is no uniform, straightforward definition for SSF (e.g. COFI, 2014). The reformed CFP defines SSF as "fishing carried out by fishing vessels of an overall length of less than $12 \mathrm{~m}$ and not using towed fishing gear". In Croatia, legislative framework recognizes only fisheries for commercial and non-commercial purposes. Commercial fisheries encompass commercial fisheries sensu stricto and the new category of small coastal fishery, limited in terms of gears and manner of operation, while non-commercial include sport and recreational fisheries (Official Gazette No. 81/2013), but usually under SSF is considered multi-gear fisheries operating with vessels $<12 \mathrm{~m}$ using all passive gears and shore seines. However, after accession to the EU, shore seines are usually exempt from analyses regarding fishing gears used by SSF. Contrary, beach seine in Montenegro represent very important fishing gear used by SSF fishers, particularly in term of total landings. This is clearly visible from total landings statistics where most of the Croatian SSF landings came from gillnets and trammel nets, while in Montenegro most of the SSF catches were landed by beach seines. Target species in total landings follow that frame and thus small pelagic fish landed by beach seines represented the bulk of catch in Montenegro, while in Croatia almost 110 different demersal fish species is regularly caught by SSF. Although, such multispecies SSF can be problematic in term of sustainable management, recent investigations suggested that such character can results in a balanced trait removal, while management should regulate the 
effects of purse-seine fisheries on the fisheries assemblage functioning (KOUTSIDI et al., 2016).

Total number of registered licenses for passive fishing gears in Croatia is pretty high because in the review of licenses prior 2008, fishers were allowed to get licenses for different fishing gears regardless of existing personal fishing track record for each gear type, and issuing of new licenses stopped in 2008 (MATIĆSKOKO et al., 2011a). This can be explanation for drastically high total number of inactive licenses (48.4\%). Regional units with highest number of fisherman and licenses (Pula and Split) have also the highest number of inactive licenses. Beside expected statistical explanation of such high percentage of inactive licenses, in mentioned counties, there is a large seasonal variation in the use of different fishing gears and targeted species. For sure, it is of high priority that in the nearest future, both countries conduct audits in term to determine the exact number of active fishers to which will be carried out a strict control of fishing activities and administrative check-out of reported landings.

Both countries use same passive fishing gears within very similar legislative framework. This is probably consequence of common past when both countries were part of same federation (MATIĆ-SKOKO et al., 2016). The fisheries legislation of the different Mediterranean countries contains a great variety of conservation/ management measures but all of them can be separated into two major categories: the fishing effort control (CADDY \& SEIJO, 2005; STEFANSSON \& ROSENBERG, 2005) and sustainable exploitation (PAPACONSTANTINOU \& FARRUGIO, 2000). Rich fishing tradition of eastern Adriatic SSF is typical Mediterranean multi-species and multi-gear fisheries sector employing more than 50 different types of fishing gear to catch about 150 different species of commercial interest (CETINIĆ et al., 2002). In the last decades, type and quantity of fishing gear with which SSF can work have been the subject of fisheries management changes (STAGLIČIĆ et al., 2011), but those legislative changes are usually more "cosmetic" in nature. However, even such small changes have the potential to shift SSF towards sustainability as it has been already shown in an offshore Adriatic region (MATIĆ-SKOKO et al., 2011a) and along eastern Adriatic coast (STAGLIČIĆ et al., 2011). In both countries, there is no catch limits and quota systems, and control of discards and by-catch will be phased out until 2019 according to e new CFP a landing obligation (DAMALAS, 2015), at least for Croatia as EU member. The second set of measures is based on provisions concerning gear specification, gear deployment, fishing practices or techniques, fishing seasons or areas, and resource exploitation patterns, which are commonly known as technical measures (PAPACONSTANTINOU \& FARRUGIO, 2000) and such type of management is characteristic for the Mediterranean. Beside this, in last years, there has been some progress towards sustainable management by means of closed seasons and areas (DI FRANCO et al., 2016). Moreover, it seems that higher discard ratio in trammel nets is more related to season then to mesh size (KALAYCI \& YEŞILÇIÇEK, 2014), which points out that direction of future sustainable management on the eastern Adriatic coast must go toward proclamation of closed area and seasons rather than numerous changes in the constructional features of fishing gears.

Comparative results of present study suggest that gillnets and trammel nets are the most widely used passive fishing gears on the eastern Adriatic coast. Trammel nets are traditionally considered as a very efficient gears with high catchability (MOROVIĆ, 1970; JARDAS, 1979), but also with low selectiveness resulting from their specific construction and operation properties (JARDAS et al., 1998; STERGIOU et al., 2006; STOBART et al., 2009). However, gillnets and trammel nets, as well as other passive fishing gears used by SSF, in general have higher mesh size and species selectivity when compared with the active fishing gears (i.e. trawls, purse and beach-seines), that can have important ecological repercussions (PALLAORO et al., 2008). Further on, the gill nets have the highest total and average fishing effort, following by trammel nets in the present study. However, average CPUE (kg/ fishing day) of trammel nets is higher than for gill nets highlighting higher unselectivity and 
greater catchability of trammel nets (FABI et al., 2002; STERGIOU et al., 2006; FABI \& GRATI, 2008; TZANATOS et al., 2013). Also, the fishing effort showed a pronounced seasonality, characterized by an increase from the minimum value in February to the maximum of June, followed by a subsequent decrease in the following months. It is worrying that the traditional seasonal use of this gears and the highest landings of certain target species coincide with the spawning of these species, when they are most vulnerable (LLORET et al., 2017), and it certainly needs to be changed when designing future measures for the protection and sustainable exploitation of marine resources in coastal Adriatic Sea.

Unfortunately, we don't have reliable data on the type, dimension and quantity of gillnets and trammel nets for accurate assessment of fishing effort STAGLIČIĆ et al. (2011) highlighted that even when such data exist, they are usually unsystematically monitored and taken. Thus, serious analysis is very complex in the Mediterranean type fisheries. We can discuss what in reality number of fishing day represent: real fishing operations or period from departure and return to fishing port as well as the real number of active fishers. Moreover, the reliability of catch statistics is also questionable since it's based on fishermen logbooks and usually not adequately systematically validated (FARRUGIO et al., 1993). Landing data from official statistics are often very far from reflecting the reality since underestimation of total catch due to misreporting and/or not quantifying discards are widespread (FARRUGIO et al., 1993; PAPACONSTANTINOU \& FARRUGIO, 2000; LLEONART \& MAYNOU, 2003) and are also not representative of the whole community as they are dominated by commercial, targeted species, compared with scientific surveys (ROCHET \& TRENKEL, 2003 and references therein). In Croatia, SSF landings can be considered as underestimated (MATIĆ-SKOKO et al., 2011), but probably the same situation can be related to Montenegrin coast. Regarding the SSF fishing effort on the eastern Adriatic coast it is probably very high as in southern Italian coastal area (COLLOCA et al., 2004), but according to available statistic data it remained steady throughout the last twenty years. This can be questionable, since large fleet sizes, short fishing trips and a small number of days at sea result in low sampling ratios attained through sampling schemes and inaccurate estimates (e.g. the overall coverage of days at sea of the 3,734 professional vessels registered in Croatia, of which the small-scale vessels are active for only 21 days annually on average, requires a great annual sampling effort that nevertheless results in poor confidence intervals in the final estimates as previously concluded by TZANATOS et al. (2013) for Greek SSFs. Moreover, the large heterogeneity of SSF activities implies differences in duration of fishing trips, in time and landing places and different sales channels representing an additional difficulty in collecting reliable information. Croatia has already in a process of systematic fisheries data collection, and, as a step of its's accession to the EU, Montenegro will also take over an obligation of accepting monitoring and data collection framework (EU Data Collection Regulations, EC no. 199/2008 and following legislation) proposed by EU in 2017.

In Croatia gillnets are used for catching several target species, and those intended to catch the hake, M. merluccius are used all year round with highest landings in June while those for gilthead seabream, $S$. aurata are mostly used in October during their spawning season. In that period, many fishermen target $S$. aurata when it is congregate inside the coastal area. In Montenegro, interestingly, Atlantic bonito, S. sarda is the dominated species both in gillnet and trammel net landings, but unfortunately, there are no monthly values for this species share in landings. Further, dominance of $S$. sarda in total landings can be unreliable due used estimation. On other side, in Croatia trammel net landings are strictly dominated by two species: the common sole, $S$. solea from November to February and the cuttlefish, Sepia officinalis in from February to May, both species during their respective spawning season. GRATI et al. (2013) concluded that the landings of the cuttlefish showed demography characterized by a strong seasonality: large specimens are dominant in catch in winter and spring in correspondence 
with the spawning period, while small individuals are predominant in summer and fall in correspondence with the recruitment phase. Most of trammel nets types used in Croatia were prohibited during late spring-summer (15 May - 10 Sept.) and in that period landings of trammel nets were lowest. Without doubt, regional differences, conditioned by the distribution of target species, exist in seasonality and frequency of their use (MATIĆ-SKOKO et al., 2011a).

The species composition of trap landings in Croatia highlighted the great selectivity by species of different traps (GRATI et al., 2010). Thus, the octopus, $O$. vulgaris was dominate species in traps for fish and traps for Norway lobster due their inappropriate use. This problem is currently hot issue in Croatian management, and a solution of including co-management that will not only empower stakeholders and share responsibilities between resource users and managers, but also become flexible, context-specific strategy where knowledge exchange between scientific and fisher's knowledge is requested (LEENHARDT et al., 2015). Contrary, N. norvegicus represented just $21 \%$ of this traps and its population state requires special attention (LLEONART \& MAYNOU, 2003). For traps, there is no landing data for Montenegrin coast as no licences for traps have been issued. Although licences were issued for drift longlines in Montenegro, the data available was considered lacking, unreliable and unsuitable for analyses and estimates. Reported catches in Montenegrin set longlines are strongly dominated by European conger, which is likely the result of the estimation methods. In Croatia, the realized catch by longlines almost fully belongs to set longlines (96\%). The highest landings of dominant species (hake, tub gurnard and European conger) usually correspond to summer months (June).

Compared to the past, fisheries management has recently adopted "ecosystem approach to fisheries" (e.g. FAO, 2003; JENNINGS \& RICE, 2011; GASCUEL et al., 2012). Therefore, future fisheries management design and implementation on the eastern Adriatic coast need to draw on insights into biological, environmental, social, and economic issues, and on how they are intercon- nected on local, regional and/or national scales as recommended more than decade ago by JENNINGS (2005). Also, involvement of fishers in management process could be effective solution for managing Mediterranean type artisanal fisheries (MATIĆ-SKOKO et al., 2011b). At the end, the Mediterranean Sea is warming in both shallow and deep waters (TZANATOS et al., 2014). However, the consequences of climate change on fishing communities will depend on exposure and the sensitivity of target species and ecosystems to climate change and fishermen's ability to adapt to climate change (GAMITO et al., 2016). Also, an increase of warmer-water species in relation to colder-water ones, and shifts in distribution affect their availability to fisheries (DULČIĆ et al., 2004; STERGIOU \& TSIKLIRAS, 2006). They suggest that Mediterranean area is expected to suffer changes in temperature and precipitation more accelerated than the global mean alteration rate. Fisheries landings fluctuations of the seven Mediterranean EU member states (Spain, France, Italy, Slovenia, Greece, Malta and Cyprus) during 1985-2008 showed significant year-to-year correlations with temperature for nearly $60 \%$ of the cases (TZANATOS et al., 2014). Increasing trends were found, mainly in the landings of species with short life spans, (VALENCIA-GASTI et al., 2015).

Such scenario is already taking place in the Adriatic waters where a significant number of thermophilic species occur in the catches more often, especially in the coastal areas (Sphyraena viridensis, Synodus saurus, Balistes carolinensis, Pseudocaranx dentex etc.) (PEĆAREVIĆ et al., 2013; TOMANIĆ, 2016). Thus, a quantification of the contribution of the number/landings of the thermophilic species to the total small-scale landings is needed. For sure, climate change will provoke changes that will be reflected in all fishery sectors, professional and recreational. Both artisanal and industrial sectors may adapt to these changes mainly through expansion of fishing grounds that will consequently increase operation costs. Trawlers may be more adaptable and less vulnerable to climate change, given the high mobility of their fleet. Multi-gear fisheries may be more flexible in changing target species 
or fishing gear, which makes them potentially less vulnerable to climate change (GAMITO et al., 2016). On the other hand, the high sensitivity of sardine to the effects of climate change makes the purse-seine fisheries particularly vulnerable to climate change. However, BELHABIB et al. (2016) highlighted that historical changes in target species are more common in industrial than artisanal fisheries. This result challenges the prevailing assumption that artisanal fisheries, given their limited movement capacity, would adapt to climate change by shifting target species and/or gear type, pointing that will make them potentially less vulnerable to climate change. For sure, changes in SSF landings provoked by climate changes are important issue on the eastern Adriatic coast and have to be monitored in proper way and on regular basis (DULČIĆ \& DRAGIČEVIĆ, 2014).

\section{ACKNOWLEDGEMENTS}

The authors would like to thank all those who were involved in SSF surveys and fisheries data collection on the eastern Adriatic coast carried out by the Institute of Oceanography and Fisheries (Croatia) and the Institute of Marine Biology, University of Montenegro (Montenegro), for their valuable help. We are grateful for the financial support to the Croatian Ministry of Science, Education and Sport and Ministry of Science of Montenegro for bilateral project BIOS (BIOdiversity and Structure of eastern Adriatic coastal fish and other marine organism communities: case studies of Croatia and Montenegro).

\section{REFERENCES}

ANNUAL ECONOMIC REPORT ON THE EU FISHING FLEET BY THE SCIEENTIFIC AND TECHNICAL COMMITTEE ON FISHERIES (STEFC), 2014. JRC scientific and policy reports. Luxembourg: Publications Office of the European Union, $368 \mathrm{pp}$.

BASTARDIE, F., ANGELINI, S., BOLOGNINI, L., FUGA, F., MANFREDI, C., MARTINELLI, M., NIELSEN, J.R., SANTOJANNI, A., SCARCELLA, G \& F. GRATI. 2017. Spatial planning for fisheries in the Northern Adriatic: working toward viable and sustainable fishing. Ecosphere, 8(2), [e01696 ]. DOI: 10.1002/ecs2.1696

BATTAGLIA, P., T. ROMEO, P. CONSOLI, G. SCOTTI \& F. ANDALORO. 2010. Characterization of the artisanal fishery and its socio-economic aspects in the central Mediterranean Sea (Aeolian Islands, Italy). Fish. Res., 102, 87-97.

BELHABIB, D., L. VWY, C. WWL. 2016. Overview of West African fisheries under climate change: Impacts, vulnerabilities and adaptive responses of the artisanal and industrial sectors. Mar. Policy, 71: 15-28.

CADDY, J.F. \& J.C. SEIJO. 2005. This is more difficult than we thought! The responsibility of scientists, managers and stakeholders to mitigate the unsustainability of marine fisheries Philos. Trans. R. Soc. Lond. B. Biol. Sci., 360: 59-75.

CETINIĆ, P., I. JARDAS, J. DULČIĆ, A. SOLDO \& A. PALLAORO. 1999. Diversity of fishing gear in coastal area of the eastern Adriatic and its influence on coastal fish communities. Proceedings of International Symposium on responsible fisheries and fishing techniques Insko-Poland, 165-176.

CETINIĆ, P., A. SOLDO, J. DULČIĆ \& A. PALLAORO. 2002. Specific method of fishing for Sparidae species in the eastern Adriatic. Fish. Res., 55: 131-139.

COFI, 2014. Report of the Technical Consultation on International Guidelines for Securing Sustainable Small-Scale Fisheries

COMMON FISHERIES POLICY (CFP) brochure. European Union, Belgium, 2014; 46 pp.

COLLOCA, F., V. CRESPI, S. CERASI \& S.R. COPPOLA. 2004. Structure and evolution of the artisanal fishery in Southern Italian coastal area. Fish. Res., 69: 359-369.

DAMALAS, D. 2015. Mission impossible: discard management plans for the EU Mediterranean fisheries under the reformed Common Fisheries Policy, Fish. Res., 2015; 165: 96-99. 
DI FRANCO, A., P. THIRIET, G. DI CARLO, C. DIMITRIADIS, P. FRANCOUR, N.L. GUTIÉRREZ, A. JEUDY DE GRISSAC, D. KOUTSOUBAS, M. MILLAZZO, M. DEL MAR OTERO, C. PIANTE, J. PLASS-JOHNSON, S. SAINZ-TRAPAGA, L. SANTAROSSA, S. TUDELA \& P. GUIDETTI. 2016. Five key attributes can increase marine protected areas performance for small-scale fisheries management. Sci. Rep., 6: 38135.

FABI, G., M. SBRANA, F. BIAGI, F. GRATI, I., LEONORI \& P. SARTOR. 2002. Trammel and gill net selectivity for Lithognathus mormyrus (L., 1758), Diplodus annularis (L., 1758) and Mullus barbatus (L., 1758) in the Adriatic and the Ligurian seas. Fisheries Research 54(3): 375-388.

FABI, G. \& F. GRATI.F. 2008. Selectivity of gill nets for Solea solea (Osteichthyes: Soleidae) in the Adriatic Sea. Sci. Mar. 72(2): 253-263.

DIRECTORATE OF FISHERIES (DF) 2015. Annual report on balance between fishing capacity and fishing opportunities for 2014 - Croatia, 24 pp.

DULČIĆ, J. \& B. DRAGIČEVIĆ. 2014. Occurrence of Lessepsian migrant Lagocephalus sceleratus (Tetraodontidae) in the Adriatic Sea. Cybium, 38 (3): 238-240.

DULČIĆ, J., FENCIL, M., MATIĆ-SKOKO, S., KRALJEVIĆ, M. \& B. GLAMUZINA. 2004. Diel catch variations in a shallow-water fish assemblage at Duće-Glava, eastern Adriatic (Croatian coast). J. Mar. Biol. Ass. UK., 84: 659-664.FAO, 2003. Fisheries management 2. The ecosystem approach to fisheries. FAO Technical Guidelines for Responsible Fisheries 4: $112 \mathrm{pp}$.

FARrugio, H., P. OliVER \& F. BIAGI. 1993. An overview of the history, knowledge, recent and future trends in Mediterranean fisheries. Sci. Mar., 57: 105-119.

FARRUGIO, H. 1996. Mediterranean Fisheries Status and Management. Evolution of the Research and Improvement of Regional Cooperation. Diplomatic Conference on Fisheries Management in the Mediterranean, Venezia (Italy), 1996; $20 \mathrm{p}$

FONT, T. \& J. LLORET. 2014. Biological and Ecological Impacts Derived from Recreational Fishing in Mediterranean Coastal Areas. Reviews in Fisheries Science \& Aquaculture 22 (1): 73 DOI: 10.1080/10641262.2013.823907

FORCADA, A., C. VALLE, J.L. SÁNCHEZ-LIZASO, J.T. BAYLE-SEMPERE \& F. CORSI. 2010. Structure and spatio-temporal dynamics of artisanal fisheries around a Mediterranean marine protected area. ICES J. Mar. Sci., 67: 191203.

FRANCOUR, P., J.G. HARMELIN, D. POLLARD \& S. SARTORETTO. 2001. A review of marine protected areas in the northwestern Mediterranean region: sitting, usage, zonation and management. Aquat. Conserv., 11: 155-188.

GAMITO, R., C. PITA, C. TEIXEIRA, M.J. COSTA \& H.N. CABRAL. 2016. Trends in landings and vulnerability to climate change in different fleet components in the Portuguese coast. Fish. Res., 181: 93-101.

GASCUEL, D., G. MERINO, R. DORING, J.N. DRUON, L. GOTI, S. GUENETTE, C. MACHER, K. SOMA, M. TRAVERS-TROLETH \& S. MACKINSON. 2012. Towards the implementation of an integrated ecosystem fleet-based management of European fisheries. Mar. Policy 36: 1022-1032.

GRATI, F., P. POLIDORI, G. SCARCELLA \& G. FABI. 2010. Estimation of basket trap selectivity for changeable nassa (Nassarius mutabilis) in the Adriatic Sea. Fish. Res. 101: 100-107. GRATI, F., M. COBANI, D. BOJANIĆ VAREZIĆ, B. DRAGIČEVIĆ, J. DULČIĆ, M. GAMBINO, O. GIOVANARDI, R. GRGIČEVIĆ, Z. IKICA, A. JOKSIMOVIĆ, J. KOLITARI, M. KRALJEVIĆ, B. MARČETA, S. MATIĆ-SKOKO, A. PALLAORO, E. SABATELLA, N. STAGLIČIĆ, J. ŠVAB, P. TUTMAN, N. VRGOČ, E. ARNERI, L. CERIOLA \& N. MILONE. 2013. Small-scale fisheries in the Adriatic Sea: information gaps at the biological, socio-economic and enviromental level. In: Dominique Bourdenet (Editor). First Regional Symposium in Sustainable Small-Scale Fisheries in the Mediterranean and Black Sea. FAO Fisheries and Aquaculture Proceedings, 39, pp. 71-82.

IKICA, Z., M. ĐUROVIĆ, A. JOKSIMOVIĆ, M. MANDIĆ, O. MARKOVIĆ, A. PEŠIĆ. 2013. Smallscale fisheries in Montenegro. In: Report on AdiriaMed technical meeting on Adriatic Sea small-scale fisheries (Split, Croatia, 
13-14 November 2012). AdriaMed Technical Documents, 33: 58-68.

JARDAS, I. 1979. Što i koliko se lovi popunicama na istočnom Jadranu? (What and in which quantities is being caught with trammel nets in the eastern Adriatic?). Morsko ribarstvo, 2-3: 51-54.

JARDAS, I. 1996. Adriatic ichthyofauna, Školska knjiga, pp 533 (in Croatian).

JARDAS, I. \& A. PALLAORO. 1997. Stanje i gospodarenje priobalnim bio-zalihama mora. (Present state and management of the Adriatic Sea bio resources) In: Božidar Finka (Editor). Book of Abstracts - "Tisuću godina prvog spomena ribarstva u Hrvata" (A thousand years ago from the first mention of fishing in Croatia). HAZU, Zagreb, pp 381399.

JARDAS, I., A. PALLAORO, M. KRALJEVIĆ, J. DULČIĆ \& P. CETINIĆ. 1998. Long-term changes in biodiversity of the coastal area of the Eastern Adriatic: fish, crustacean and cephalopoda communities. Period. Biol., 100: 19-28.

JENNINGS, S. 2005. Indicators to support an ecosystem approach to fisheries. Fish Fish., 6: 212-232.

JENNINGS, S. \& J. RICE. 2011. Towards an ecosystem approach to fisheries in Europe: a perspective on existing progress and future directions. Fish Fish., 12: 125-137.

KALAYCI, F. \& T. YEŞILÇIÇEK. 2014. Influence of season, depth and mesh size on the trammel nets catch composition and discard in the Southern Black Sea, Turkey. Mar. Biol. Res., 10 (8): 824-832.

KOUTSIDI M., E. TZANATOS, A. MACHIAS \& V. VASSILOPOULOU. 2016. Fishing for function: the use of biological traits to evaluate the effects of multispecies fisheries on the functioning of fisheries assemblages. ICES J. Mar. Sci. 73 (4): 1091-1103.

LEENHARDT P., L. TENEVA, S. KININMONTH, E. DARLING, S. COOLEY \& J. CLAUDET. 2015. Challenges, insights and perspectives associated with using social-ecological science for marine conservation. Ocean Coast. Manag. 115: 49-60.

LLEONART, J. \& F. MAYNOU. 2003. Fish stock assessment in Mediterranean: state of the art. Sci. Mar., 67: 37-49.
LLORET, J., I.G. COWX, H. CABRAL, M. CASTRO, T. FONT, J.M.S. GONÇALVES, A. GORDOA, E. HOEFNAGEL, S. MATIĆ-SKOKO, E. MIKKELSEN, B. MORALES-NIN, D. MOUTOUPOLOS, M. MUÑOZ, M. NEVES DOS SANTOS, P. PINTASSILGO, C. PITA, K.I. STERGIOU, V. ÜNAL, P. VEIGA \& K. ERZINI. 2016. Coastal fisheries in European Seas are not what they were: ecological, social and economic changes in small scale fisheries. Marine Policy, 2017. doi: 10.1016/j.marpol.2016.11.007

NARODNE NOVINE (NN). 2013. Zakon o morskom ribarstvu (Official Gazette of Croatia: Marine Fisheries Law). 81/2013.

MATIĆ-SKOKO, S., N. STAGLIČIĆ, A. PALLAORO, M. KRALJEVIĆ, J. DULČIĆ, P. TUTMAN \& B. DRAGIČEVIĆ. 2011a. Effectiveness of conventional management in Mediterranean type artisanal fisheries. Estuar. Coast. Shelf. S., 91: 314-324.

MATIĆ-SKOKO, S., N. STAGLIČIĆ, M. KRALJEVIĆ, A. PALLAORO, P. TUTMAN, B. DRAGIČEVIĆ, R. GRGIČEVIĆ \& J. DULČIĆ. 2011b. Croatian artisanal fisheries and the state of it's littoral resources on the doorstep of entering the EU: effectiveness of conventional management and perspective for the future. Acta Adriat., 52: 87-100.

MATIĆ-SKOKO, S., N. STAGLIČIĆ, D. BLAŽEVIĆ, J. ŠILJIĆ \& D. IRITANI. 2016. In: Daniel Pauly and Dirk Zeller (Editors). Croatia. Global Atlas of Marine Fisheries. p. 232.

MOROVIĆ, D. 1970. Ribolovni alat popunica i analiza lovina s biološkog aspekta. (Trammel net and analysis of the catch from biological standpoint). Morsko ribarstvo 22, 119-122.

PALlAORO, A., DULČIĆ, J., MATIĆ-SKOKO, S., KRALJEVIĆ, M. \& I. JARDAS. 2008. Biology of the salema, Sarpa salpa (L. 1758) (Pisces, Sparidae) from the middle eastern Adriatic. J. Appl. Ichthy., 24: 276-281.

PAPACONSTANTINOU, C., \& H. FARRUGIO. 2000. Fisheries in the Mediterranean. Mediterr. Mar. Sci., 1: 5-18.

PEĆAREVIĆ, M., J. MIKUŠ, A. BRATOŠ CETINIĆ, J. DULČIĆ \& M. ČALIĆ. 2013. Introduced marine species in Croatian waters (Eastern Adriatic Sea). Mediterr. Mar. Sci., 14: 224-237. 
PEŠIĆ, A., A. JOKSIMOVIĆ, M. ĐUROVIĆ, O. MARKOVIĆ \& Z. IKICA. 2016. Characteristics of small-scale fisheries in Montenegro (south Adriatic Sea). HydroMediT 2016 - 2nd International Congress on Applies Ichthyology \& Aquatic Environment, 10-12 November 2016, Messolonghi, Greece. Conference Proceedings, pp. 311-315.

ROBERTS, C.M., J.P. HAWKINS \& F.R. GELL. 2005. The role of marine reserves in achieving sustainable fisheries. Phil. Trans. R. Soc. B., 360: 123-132.

ROCHET, M.J. \& V.M. TRENKEL. 2003. Which community indicators can measure the impact of fishing? A review and proposals. Can. J. Fish. Aquat. Sci., 60: 86-99.

SALAS, S. \& D. GAERTNER. 2004. The behavioral dynamics of fishers: Management implications. Fish Fish., 5: 153-167.

SLUŽBENI LIST CRNE GORE. 2009. Zakon o morskom ribarstvu i marikulturi (Official Gazette of Montenegro: Law on Marine Fisheries and Mariculture). 56/09.

SLUŽBENI LIST CRNE GORE. 2015. Zakon o izmjenama Zakona o morskom ribarstvu i marikulturi (Official Gazette of Montenegro: Law on changes of the Law on Marine Fisheries and Mariculture). 47/15.

STAGLIČIĆ, N., S. MATIĆ-SKOKO, A. PALLORO, R. GRGIČEVIĆ, M. KRALJEVIĆ, P. TUTMAN, B. DRAGIČEVIĆ \& J. DULČIĆ. 2011. Long-term trends in the structure of eastern Adriatic littoral fish assemblages: Consequences for fisheries management. Est. Coast. Shelf Sci., 94(3): 263-271.

STEFANSSON, G. \& A.A. ROSENBERG. 2005. Combining control measures for more effective management of fisheries under uncertainty: quotas, effort limitation and protected areas. Philos Trans R Soc Lond B Biol Sci 360: 133-146.

STERGIOU, K.I., D.K. MOUTOPOULOS, M.C. SORIGUER, E. PUENTE, P.G. LINO, C. ZABALA, P. MONTEIRO, L.A. ERRAZKIN \& K. ERZINI. 2006. Trammel net catch species composition, catch rates and métiers in southern European waters: a multivariate approach. Fish. Res., 79: 170-182.
STERGIOU, K.I. \& A.C. TSIKLIRAS. 2006. Underrepresentation of regional ecological research output by bibliometric indices. Ethics Sci. Environ. Polit., 2006: 15-17.

STOBART, B., R. WARWICK, C. GONZÁLEZ, S. MALLO, D. DÍAZ, O. REÑONES, \& R. GOÑI. 2009. Long-term and spillover effects of a marine protected area on an exploited fish community. Mar. Ecol. Prog. Ser., 384: 47-60.

TOMANIĆ, J. 2016. Nove vrste riba i rakova na Crnogorskom primorju (južni Jadran) (New fish and crustacean species in Montenegrin waters (south Adriatic)). Master thesis, Biological faculty, University of Belgrade, 57 pp.

TUTMAN, P., A. ŽULJEVIĆ, I. CVITKOVIĆ, M. PAVIČIĆ, J. ŠILJIĆ \& D. BOJANIĆ VAREZIĆ. 2015. Ghost-net fishing along the Croatian coastline; occurrence and biological impact on marine biodiversity, a preliminary assessment. In the Wake of Plastics / Pojana, Giulio (Editor). Venetia: University $\mathrm{Ca}^{\prime}$ Foscari. 29-29.

TZANATOS, E., J. CASTRO, A. FORCADA, S. MATIĆSKOKO, M. GASPAR \& C. KOUTSIKOPOULOS. 2013. A Métier-Sustainability-Index (MSI25) to evaluate fisheries components: assessment of cases from data-poor fisheries from southern Europe. ICES J. Mar. Sci., 70 (1): 78-98.

TZANATOS, E., D.E. RAITSOS, G. TRIANTAFYLLOU, S. SOMARAKIS \& A.A. TSONIS. 2014. Indications of a climate effect on Mediterranean fisheries. Clim. Change., 122: 41-54.

VALENCIA-GASTI, J.A., T. BAUMGARTNER \& R. DURAZO. 2015. Effects of ocean climate on life cycles and distribution of small pelagic fishes in the California Current System off Baja California. Cienc. Mar., 41(4): 315-348.

VRGOČ, N., PEHARDA ULJEVIĆ, M. \& S. KRSTULOVIĆ ŠIFNER. 2009. Assessment of demersal fish and shellfish stocks commercially exploited in Croatia. Final Output of the European Union's PHARE 2005 Project: EuropAid/123624/ SER/HR program. $172 \mathrm{pp}$. 


\title{
Usporedba hrvatskog i crnogorskog priobalnog ribolova na istočnoj obali Jadrana: ribolovni alati i ciljane vrste
}

\author{
Sanja MATIĆ-SKOKO, Zdravko IKICA, Dario VRDOLJAK, Melita PEHARDA, \\ Pero TUTMAN, Branko DRAGIČEVIĆ, Aleksandar JOKSIMOVIĆ, Jakov DULČIĆ, \\ Mirko ĐUROVIĆ, Milica MANDIĆ, Olivera MARKOVIĆ, Nika STAGLIČIĆ \\ i Ana PEŠIĆ*
}

*Kontakte-adresa: pesica@ac.me

\begin{abstract}
SAŽETAK
Priobalni ribolov u Hrvatskoj i Crnoj Gori ima dugu tradiciju kao uostalom i cijelom obalnom području Sredozemnog mora. Znanstvenici i ribarstveni gospodarstvenici koji su uključeni u ovu problematiku u obje zemlje su uložili napor kako bi se bolje upoznale ribolovne aktivnosti i ciljane vrste, i time poboljšalo upravljanje priobalnim resursima i spasilo kulturno nasljeđe ribarske tradicije na istočnoj obali Jadrana. Istraživanje priobalnog ribarstva je složeno pitanje zbog visokog ribolovnog pritiska na morske resurse i činjenice da je gospodarenje ribarstvom na području cijelg Sredozemlja još uvijek konvencionalno po svojoj naravi. Osnovne karakteristike priobalnog ribarstva su prikazane u svakoj zemlji. Specifični zaključci koji se odnose na poboljšanje stanja priobalnih resursa u smislu održivog korištenja su predloženi, zajedno s prijedlogom za dodatne mjere zaštite i aktivno uključivanje ribara u proces upravljanja. Naposljetku, smjernice za buduće upravljanje u smislu praćenja i prikupljanja podataka u ribarstvu su predloženi za obje zemlje.
\end{abstract}

Ključne riječi: priobalni ribolov, Jadransko more, Crna Gora 